
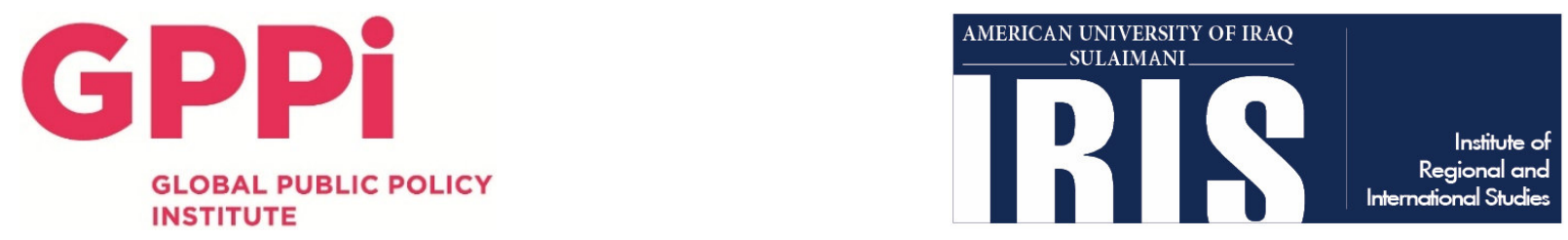

January $2017^{*}$

\title{
Backgrounder: Literature Review of Local, Regional or Sub-State Defense Forces in Iraq
}

\section{By: Erica Gaston, Andras Derzsi-Horvath, Christine van den Toorn, Sarah Mathieu-Comtois}

Regional or community forces, militias, and other forms of local security actors have long existed in Iraq, supported either by local political actors or parties, regional actors, or non-state groups. However, in the last two years, these local and hybrid security forces have proliferated. Peshmerga forces and a range of Shia and tribal militia forces, or local defense forces could be quickly mobilized to counter the threat posed by ISIL and fill gaps in the Iraqi Security Forces (ISF). What has been the impact of these groups for community and political dynamics, prospects for stabilization in liberated areas, and other rule of law, governance, and rights concerns? What will be the future position of these groups after the immediate crisis is resolved, and how will the greater reliance on these quasi- or non-state actors impact the long-term prospects for the Iraqi state?

\section{Background}

The aim of this project is to explore Local or Hybrid Security Forces (LHSF) in Iraq and Afghanistan from a comprehensive security perspective, with a particular emphasis on how these forces are affected by foreign support or assistance, and transnational or regional security threats. Research will be led by the Institute for Regional and International Studies (IRIS) at the American University of Iraq, Sulaimani (AUIS) in Iraq, and the Afghanistan Analysts Network (AAN) in Afghanistan, in cooperation with the Global Public Policy Institute (GPPi) in both countries. This Consortium will approach the impact of militias, local or regional defense forces or hybrid, quasi-state forces from a comprehensive security perspective, considering not only whether these groups have contributed to security and stabilization goals, but also how they have affected community dynamics and empowerment, the protection of civilians and human rights, and other political, rule of law and governance dynamics. This research is supported by the Netherlands Organisation for Scientific Research. Given the focus on

\footnotetext{
* This is a working draft, which will be updated over the course of the project (until May 2019). This draft is not available for citation but comments or additional research sources could be shared with egaston@gppi.net.
} 
regional security threats or dynamics, the research may also consider issues regarding LHSFs in Syria, but only to the extent that they overlap with the anti-ISIL campaign or forces examined in Iraq. The outputs will be a series of research papers, some taking a comparative approach, but others focused exclusively on national or local dynamics within Iraq or Afghanistan.

This project aims to generate new evidence- and field-based insights that complement and build from existing research and analysis. As such, an important first step in the research process was to survey existing academic, policy and practitioner literature to identify open research questions or gaps in existing literature. This was complemented by preliminary stakeholder interviews and consultations with those with knowledge of current trends and needs observed in Iraq, or expertise in the particular subject matter areas.

This background note briefly summarizes some of the existing literature surveyed about the impact of LHSFs for four key subject areas:

1. Security effectiveness;

2. Long-term impact and concerns for state-building;

3. Human rights and protection concerns;

4. Community dynamics, rule of law and local governance.

This literature review only focuses on existing public sources, not the independent research or stakeholder research conducted as part of this project, nor non-public reports shared with researchers.

\section{Definitions}

This project is interested in pro-government non-state or sub-state forces, including militias, local or community defense forces, and regional or hybrid, quasi-state forces. The plethora and fluidity of armed groups in Iraq frequently challenge definition. Formally, Iraqi law is clear that local police, the federal police, the counter-terrorism service and the army constitute the official security forces (Knights 2016). Armed groups operating "outside the framework of the armed forces" are prohibited under Article 9 of the Iraqi constitution. However, in practice it has not always been easy to distinguish official state forces from non-state (and thus illegal) forces. Before 2014, pro-government militias often acted upon the government's behest, especially during Prime Minister Maliki's second term, from 2010 to 2014. Conversely, some would argue the formal state security apparatus often acts along sectarian or partisan lines. The Iraqi federal police were notably awash with Shia militiamen during the periods when the ministers of interior were linked to the Badr Organization, from 2005 to 2006 and 2014 to 2016. With the organization of non-state militias or local forces into the Popular Mobilization Forces (PMF) in 2014, and formal incorporation into the security apparatus in 2016 (the full effect of which is yet unclear), the line between non-state armed groups and official forces has become even more attenuated.

Another tension in the definitions is the extent to which these groups could be defined as "local" or "community-based." Prior to 2014, most of the pro-government militias - from the Sunni Sahwa, or "Awakening" forces to the Shia militias - were overwhelmingly locally recruited and deployed, often performing local policing and security functions. With the onset of ISIL and the conflict in Syria, this 
dynamic has shifted. Shia militias fighting ISIL have been mobilized from Shia strongholds, in the south of the country, and deployed to the often predominantly Sunni heartlands that ISIL has taken over. From 2012 to 2014, many of these Shia militias, closely affiliated with Iran, were deployed in Syria to fight on behalf of Bashar al-Assad. Nonetheless, although nowhere near the number of Shia militia units, there are many units within the PMF that are drawn from local Sunni and Shia Arab, Turkmen, and Christian communities where fighting is taking place.

The Peshmerga are also difficult to categorize. Article 117 of the 2005 Iraqi Constitution allows regions to establish their own internal security services, the "police, security forces and guards of the region," and the Peshmerga are legally recognized as one of these permissible regional groups (so far the only one). They have an organized command structure and effective control of territory that is more similar to a state entity than a militia or other armed group. In practice, they often behave like a state force, albeit sharing some of the similar political fluidity of Iraqi Security Forces and acting at the behest of political leaders or parties. Given all of these factors, the Peshmerga would arguably be categorized more as a state force, however, they are important to include as a point of comparison for some aspects of this project given the likelihood that other sub-state forces will be formalized, or that other regional forces will develop along the model (or at an equivalent status) to the Peshmerga. As the only regional force recognized so far, the Peshmerga present one end of the spectrum and may offer important comparative insights for future policy prescriptions surrounding the other groups.

The annex to this document includes an overview of all of the groups considered under the scope of LHSFs, at least for this preliminary background review, including the PMF, and the range of sub-units and forces that fall under that umbrella definition, as well as tribal forces, the Peshmerga, the Kurdish Worker's Party (PKK) and its affiliates, and local ethnic or religious forces that have arisen in response to the threat from ISIL, including Ezidi and Christian militias.

\section{Security Effectiveness}

Key questions: What has been the contribution of LHSFs in addressing recent or ongoing security concerns in Iraq? Is there any evidence that LHSFs fare better or worse against transnational elements than state forces? In addition to supporting tactical gains against ISIL or opposition elements, is there evidence that LHSFs increase stability? Does reliance on these groups have negative repercussions for other security elements, such as on inter-ethnic, inter-communal, or inter-state violence?

Most observers credit the PMF and the Peshmerga with being instrumental in stopping ISIL's quick advance following the fall of Mosul in June 2014. These forces also spearheaded the initial offensives against ISIL in 2014 and have since participated in almost all major anti-ISIL campaigns alongside the Iraqi Security Forces. In addition to the PMF and Peshmerga, most also credit the forces aligned with the Kurdish Worker's Party (PKK) with some substantial military victories, notably cutting a humanitarian corridor through ISIL's siege of Ezidis trapped on Mount Sinjar in August 2014 (see, Ali and Kagan 2014).

However, while popularly credited with decisively affecting the campaign against ISIL, there have so far been few studies that conclusively address how effective LHSFs in Iraq are at providing security and 
stability. RAND's Robinson (2016) ranks the military capability of three of the most relevant groups the Peshmerga, the PKK-affiliated People's Defense Unit (YPG) and the PMF's Shia militias - higher than the Iraqi army's (but equal or lower than that of the Counter-Terrorism Service). Cigar (2015) and Robinson (2016) argue that compared to the formal security forces, local and hybrid security forces show signs of higher fighting morale, greater unit cohesion, and tactical superiority especially in areas where mechanized units cannot operate. ${ }^{1}$ These estimations may also change over time. The strength of the PMF and non-state actors is largely due to the weakness and collapse of the ISF in 2014 when ISIS attacked, PMF and other LHSFs may have been the most effective security option at the time. Since then, however, ISF have reformed and been rebuilt to an extent, and have had major battlefield successes, particularly the Iraq Special Forces (the so-called "Golden Division") and Iraqi Counter Terrorism Forces (ICTF), and significantly more so than the PMF in places like Ramadi, Fallujah and during the initial stages of the Mosul campaign.

Other studies have pointed to equally compelling drawbacks in terms of LHSF's security effectiveness. The Peshmerga and newly formed units within the Popular Mobilization Forces have comparably less relevant fighting experience and only rudimentary training, which impairs their effectiveness (Cigar 2015; Beck 2014). Contested or loose political control is another factor detracting from LHSF effectiveness, and there have been critiques of the strategic incoherence between different PMF units (Sowell2015a), and concerns about rivalries between the Kurdistan Democratic Party (KDP)- and Patriotic Union of Kurdistan (PUK)-led Peshmerga (Fumerton and Van Wilgenburg (2015)). Others have also pointed out that LHSFs engaged in the anti-ISIL campaign (particularly PMF) are highly dependent on the air support provided by the ISF and the US-led anti-ISIL Coalition (Cigar 2015). Wehrey and Ahram (2015) argue that PMF failed to counter ISIL even with superior number of forces (see also Sowell 2015a). They also note the fact that many of the PMF refused to work with American forces, as well as the "campaign of terror" they unleashed on the Sunni population, makes them less than ideal military partners (Wehrey and Ahram 2015).

Many observers have raised similar concerns that reliance on LHSFs in the campaign against ISIL will raise greater long-term security concerns and instability. Amnesty International has argued that sectarian attacks, retaliation, and targeting of civilians is at a level not seen since 2006/2007 (Amnesty, 2014). It argues that the unregulated and unaccountable militias will be a cause for instability in the future (Amnesty 2014). Pollack (2016a; 2016b) foreshadows more violence in the likely scenario of ISIL's defeat in Mosul, as the grievances of Iraq's Sunni Arab population have only been exacerbated by the unlawful conduct of LHSFs in combat and beyond (e.g., preventing the return of displaced populations).

There has been less available research and analysis considering the security effectiveness of smaller minority militias or units within PMF and Peshmerga, or their contribution to stability, no doubt due to their small numbers and relatively peripheral role in much of the fighting.

\section{State-building and Long-term Impacts}

Key questions: How does the proliferation or reliance on LHSFs impact long-term political and conflict dynamics? How does empowering local security actors affect the development of the rule of law and 
legitimate governance, both locally and nationally? Is there potential for militias, local or regional security forces to rival state-led armed services, undermine state control and overall stability?

While LHSFs in Iraq have received praise for their successes in the war against ISIS, many have argued the negative medium- and long-term consequences are likely to far outweigh current battlefield gains. The research and analysis that exist so far suggest that the presence of multiple and competing foreignbacked militias, which has characterized the Iraqi context for over two years, has challenged and delegitimized the authority of the state, deepened ethno-sectarian and partisan fault lines, and increased subnational (intercommunal, interethnic, and inter-militia) conflict.

With the military defeat of ISIL, other grievances and tensions might come to the fore, with LHSFs at the forefront of escalating intercommunal, interethnic or partisan conflict. Journalists and commentators have documented fault lines within the anti-ISIL coalition and suggested that with the defeat of the common enemy these underlying tensions will re-emerge, sparking conflict along sectarian and partisan fault lines between rival PMF factions or between the PMF and the Peshmerga. Christoph Reuter and Iraq Oil Report have documented this type of subnational conflict emerging already in Tuz Khurmatu between Shiite Turkmen and Kurdish forces (Reuter 2016; van den Toorn \& Lacky 2014; Iraq Oil Report staff 2015). Mustafa Habib (2015) has warned that after the fall of ISIL, the three major divisions within the Shia militias may become more prominent and manifest into serious military and political conflict as the groups jockey for power in the lead up to 2017 provincial elections (see also Aghuan 2015).

Both Iranian-backed Shia militias and Western-backed Kurds have used their increased weaponry and territorial control to implement maximalist rather than 'accommodationist' policies in post-ISIS liberated areas, deepening divisions and animosities between ethno-sectarian communities. As Natali (2015) argues in a policy piece, "Peshmerga forces are using coalition air strikes to engineer territorial and demographic changes that are antagonizing Sunni Arabs-the very communities the United States needs on its side to degrade ISIS" (see also Puttick 2014). Shia militias have been accused of ethnic- or sectarian-based property destruction, and preventing Sunni populations from returning, with the effect of deepening sectarian tensions and increasing the chances of retaliation and sectarian violence across the country (Hiltermann 2016; Fahim 2015).

Craig Whiteside (2016) has pointed to the underlying dilemma that, in order to defeat the Islamic State, the US and its Iraqi partners rely on sectarian actors, whose empowerment would undermine the prospects for reconciliation, which is necessary for long-term stability and state cohesion.

\section{Undermining the Iraqi State}

A longstanding critique within the academic literature has been that supporting non-state forces can detract from long-term state-building by exacerbating competition for power and legitimacy in a state already struggling to maintain authority and control (Hughes and Tripodi 2009). This argument has emerged forcefully in discussions of the growing power of the PMF and the decreasing perceived legitimacy and strength of the ISF (Sowell 2015b; Mansour 2016a). PMF raise a fundamental sovereignty issue for the Iraqi state, which will only increase if they become more powerful than the 
national army, some have argued (Davis 2016). Some would argue that the November 2016 PMF law passed by Parliament mitigates this risk by incorporating PMF into the ISF (and thus no longer presenting non-state competition for them); however, the full effect of this law and the degree of Iraqi state control over these forces in practice remains to be seen.

The PMF law includes a provision that PMF members may not seek public office, a potential response to concerns that the PMF militias would seek to expand political power in coming election cycles. Iranian-backed Shia militias have a history of infiltrating government offices, as noted by Perito (2008), and their ability to capture the state has only increased since 2014, as their perceived military effectiveness and greater control of their territory has enhanced their political power and position (Sowell 2015b). Writing for Carnegie in August 2015, Sowell (2015c) warned that, "[b]ecause of the war in Anbar, the 2014 parliament is more sectarian and more Shia Islamist than the 2010 parliament," and current trends suggest further militia gains in the upcoming 2017 provincial elections and 2018 national elections.

In addition to threatening the legitimacy and governance of Iraqi institutions, if the past is any guide, increased integration of sectarian militia groups into the government would trigger future cycles of violence. Krieg (2014) has argued that Maliki’s reliance on sectarian militant groups was largely responsible for alienating Kurdish and Sunni communities, and pushed them into the arms of "religious militias, neighborhood watches, and tribal insurgent groups." This was the primary reason for the failure of past security sector reforms, he argues, which opened the door for ISIL.

Finally, some commentators have expressed fears that greater Shia militia control over the government would increase Iranian control and influence on Iraqi politics (Young 2015), or potentially open the door for a shift to a more Iranian-style theocracy (McGeough 2012).

\section{Impacts on the Kurdistan Region of Iraq (KRI)}

Rather than uniting Kurdish forces under a "war against ISIS" banner, the conflict, and foreign backing, has further divided and increased the competition between Kurdish political parties (Fantappie 2015; Wahab 2015). The International Crisis Group (2015) warns about the possible fallout between the political factions controlling the Peshmerga following ISIL's defeat - a process that has been accelerated by foreign assistance and little control over how the US-led Coalition's arms are distributed among the KDP- and PUK-commanded forces of the Peshmerga (ICG 2015). This will tend to weaken democratic processes and governance within the Kurdistan Regional Government (KRG) (Wahab 2015). ICG (2015) also warns that Cdioalition support to the Peshmerga and efforts to empower the Kurds might also upset the delicate balance between Erbil and Baghdad, which will impact the debate over Kurdish independence and the long-due referendum that would decide control over Iraq's disputed territories (DIBs) (see also van den Toorn and Mathieu-Comtois 2016).

\section{Regional Tensions}

Finally, the way that internal dynamics unfold in Iraq could trigger regional tensions across several different dimensions. The provision of weapons and support to Kurdish Peshmerga in Syria and 
cooperation with PKK-affiliated militias in Iraq have already raised Turkish concerns and led to more aggressive Turkish engagement in Iraq (Arango and Gordon 2016); most recently, the deployment of PKK-affiliated fighters and Iranian-backed Shia militias around Tel Afar, West of Mosul, have prompted a growing Turkish military presence (mainly along the border) and increased the likelihood of a more aggressive Turkish involvement in Iraq (Kavalek 2016). This tension could not only upset Turkey's bilateral relations with Iraq and Iran, but could also hinder the potential for a regional framework for action to address ISIL or the issues in Syria (Natali 2015). The deployment of PKKaffiliated fighters and Iranian-backed Shia militias around Tel Afar, West of Mosul, has increased Turkish deployment along the border and the likelihood of greater Turkish military involvement in Iraq (Kavalek 2016). A greater role and sway for Iranian-backed Shia militias could lead to Gulf monarchies arming Sunni militias, and could further destabilize the situation in Syria and Jordan (Moyar 2015). There is further concern that once the major conflict with ISIL is over in Iraq, Iraqi Shia militias might be redeployed to Syria, potentially re-escalating the conflict there (ACAPS 2014).

\section{Human Rights and Protection Concerns}

Key questions: What is the evidence of the human rights record of LHSFs? Are there any policy or academic studies that suggest whether LHSFs are better or worse in meeting protection standards? How do mechanisms such as human rights screening or vetting, training or other donor-enforced accountability mechanisms for those supported work in practice?

Journalists, human rights activists, and international organizations have documented significant rights abuses by Iraqi militias and LHSFs. PMF militias stand accused of the most egregious rights violations, although Peshmerga and others have also been accused of committing serious violations of international and domestic law.

Human rights allegations have followed Shia PMF operations wherever they were deployed since 2014, with the most frequent and egregious allegations surrounding the conduct of the pro-Iranian militias the Badr Brigades, the League of the Righteous and Hezbollah Brigades. Human Rights Watch (HRW) and Amnesty International (AI) documented human rights violations that follow a pattern of ethnic abuse and retaliation, using summary executions, torture, arbitrary detentions, and abuse against the Sunni population, including in Jurf al-Sakhr (HRW 2014, Rasheed and Georgy 2014, Parker and Rasheed 2014), near Muqdadiya (AI 2015a, HRW 2016b), Tikrit (HRW 2015d) and Falluja (HRW 2016e). Such abuses have frequently been accompanied by large-scale patterns of forced displacement, property destruction and the prevention of return, according to the same reports. AI and HRW also noted significant property destruction in and around Sleiman Beg, near to Amerli, but did not report extrajudicial killings (AI 2014, HRW 2015a).

ISF have not been directly implicated in the abuses by these Popular Mobilization Forces, but HRW and others have argued that ISF clearly is aware of these abuses, and permits them to go on or is unable to intervene, making it somewhat complicit (HRW 2014). There have been allegations of ISF engaging in extrajudicial killings and other violations of international humanitarian law (IHL), but the United States Department of State has estimated that the ISF has abused rights "to a much lesser extent" than the PMF in recent anti-ISIL operations (but see Parker 2015 on federal police abuses). 
The Peshmerga and other Kurdish forces have also been implicated in ethnic "clearing" policies preventing or discouraging the return of Arab communities to DIBs through mass property destruction, or denying Sunni Arabs access to newly liberated areas. These allegations have sometimes risen to the level of ethnic cleansing in Nineveh, Erbil and Kirkuk governorates (HRW 2015b, 2016c, AI 2016). The Peshmerga have also been accused of collective punishment and mistreatment of the Sunni Arab populations, including unlawful detention, serious restrictions on movement, limitations to humanitarian aid, and looting and torching the property of those suspected of supporting attacks against the Peshmerga (Van den Toorn 2016, HRW 2015b). They have also allegedly abused and tortured detainees suspected of links with ISIL, a violation of IHL (HRW 2015b).

Rights organizations have documented frequent retaliatory attacks against rival groups (or civilians associated with those groups) in DIBs by multiple different parties. Enmity between Kurds and Shia Turkmen in the recently liberated contested areas have resulted in a tit-for-tat between these PMF and Peshmerga forces, both often retaliating against civilians where their forces are harmed (HRW 2016a). Forces representing local communities have also engaged in unlawful retaliatory attacks. Reuters' Coles (2015) and AI (2015b) reported of summary executions perpetrated by Ezidi militias in areas north of Sinjar. The degree of Peshmerga complicity in these attacks is unclear, but the UN Assistance Mission for Iraq (UNAMI) (2015) found that the PKK's Syrian affiliate, the YPG, and local Ezidi militias were responsible for the violations, not the Peshmerga.

Finally, in addition to abuses of civilians, multiple sides have been accused of forced recruitment and child soldiers, notably several PMF units, including the First Martyr Movement/Free Iraqis (Salama and Abdul-Zahra 2016), the Abbas Combat Division and the Peace Brigades (Wilke 2016); and the PKK's Syrian offshoot (IRIS field research in 2016).

\section{Human Rights Accountability and Prevention of Abuse}

Despite significant and widespread abuses by many LHSFs, the lack of detailed information on the identity and affiliation of perpetrators have made criminal persecution and foreign sanctions difficult. Although in some cases the Iraqi government and the KRG have instituted commissions of inquiry, findings have not been shared publicly. In the case of the KRG, their findings did not correspond to those of HRW (2016c). There is no record of an LHSF member disciplined or sentenced by Baghdad or Erbil for committing gross human rights abuses in Iraq (HRW 2016c, Wilke 2016).

There is a lack of data on whether and how those training or supporting LHSFs - from the Iraqi government to foreign sponsors such as Iran or Western governments - address human rights concerns to ensure that LHSFs receiving security assistance do not commit abuses. Members of the US-led Coalition incorporate Laws of Armed Conflict (LOAC) and human rights in their training of the Peshmerga (MERI 2016), and reportedly raise complaints where allegations of abuse surface (Williams 2015).

There have also been limited instances of suspension of assistance where allegations of abuse or misuse arose. For example, Germany temporarily suspended arms exports to the Peshmerga in early 2016, following information that weapons it supplied were resold in markets. Many of the forces equipped or 
trained by the United States, directly or indirectly, would also be subject to vetting under the Leahy amendment, which would require units cut off from support where credible allegations of gross human rights violations manifested (Serafino et al. 2014). The Leahy amendment only applies to state forces, however, so may not be applied to all forces being supported in Iraq. In 2016, the United States granted a one-year waiver to Iraq on the applicability of the US Child Soldiers Prevention Act. Absent this waiver, all security assistance funding would likely have been suspended, given the prevalence of allegations of use of child soldiers throughout pro-government forces (HRW 2016d).

\section{Community Dynamics and Empowerment}

Key questions: How does the mobilization of local security forces affect local power dynamics, the degree of community empowerment or political expression that communities have vis-à-vis other groups? Are LHSF forces in Iraq representative of local communities, and are they perceived as legitimate? Are LHSFs accountable to, or able to be controlled by local communities in any way?

There have been relatively fewer studies that have specifically analyzed how LHSFs affect community empowerment at a micro-level (district or village), but there is some literature available on the preferences, concerns or political leverage of communities as a whole, at the level of entire sectarian or ethnic communities. This section will discuss perceptions of legitimacy and support for LHSFs among these larger communities or groups; the way that LHSFs conduct and empowerment will likely affect future community political preferences, reconciliation, and trust vis-a-vis other community groups; proposals for greater attention to grassroots, community-brokered solutions, decentralization, and local empowerment measures as a way to increase the chances of short- and long-term stability.

\section{Legitimacy and Support of LHSFs}

The degree of legitimacy and support that particular LHSFs enjoy is a contested question, highly dependent on the differing regional, national and subnational political and identity conflicts, but also on the experience of particular communities with these forces.

Community support for PMF forces and the degree of legitimacy they enjoy is in general higher in areas where they are traditionally based and recruit from (typically in the south). Many pieces present evidence suggesting the level of community buy-in and strength of Iranian-affiliated militias such as the Badr Brigades, Asaib Ahl al-Haq (AAH), and Hezbollah Brigades in the Shia strongholds of Karbala, Basra, Al-Muthanna, and Babil (Cigar 2016; Sowell 2015a, 2015b). By contrast, Shia militias have low legitimacy and support in Sunni areas where they are currently engaged against ISIL, in part due to longstanding sectarian tensions but also because of the extensive human rights violations, sectarian retaliation, and prevention of return that were documented in the human rights section of this paper (Younis 2015; Sowell, 2015b; Mansour 2016b; Vimont 2015). Yet despite their reputation for being unpopular among Sunni tribes, there have been cases in which Sunni populations have joined and fought alongside Shia militias or PMF, notably Badr (Mello and Knights).

There have not yet been sufficient studies examining how inclusion of prominent local tribes and forces alongside PMF, ISF, or other 'outsider' forces increase the perceived legitimacy or local trust in 
operations. The decision to mobilize Sunni tribes in Anbar and in Ninevah (with estimates of 35,000 forces authorized, 20,000 in Anbar and 15,000 in Ninevah) as part of the Hashd al-Ashairi appears at least partly motivated by such concerns, and by the negative reaction following PMF advances on Tikrit. Analyzing the operations around Falluja, Gulmohamad (2016b) noted that the stabilization phased was helped by the fact that there were local tribal forces and locally recruited police helping to reassure civilians and securing some areas.

Although some would argue that the Peshmerga and the KRG in general have gained legitimacy in the fight against ISIL (in part due to extensive foreign backing), the Peshmerga's image as protector of minorities in the DIBs was damaged when their forces retreated in Sinjar and other minority areas around Mosul ahead of ISIL's advance in the summer of 2014, exposing tens of thousands to violence (Chulov and Hawramy 2014). Natali (2015) argues that their so-called "scorched earth policy" in retaken Arab villages surrounding the KRI, as well as the fact that the Peshmerga have prevented the return of Arab families in some areas, have strained their relationship with local communities outside the KRI.

\section{Co-option Versus Local Empowerment in Local Militias and Proxies}

The contest between the KRG and Baghdad for the control of DIBs has encouraged different co-option and alliance strategies with local Sunni and minority communities.

"Minority" militias and forces have existed in Iraq over the past decade, but their presence and power has increased since the ISIL attack. Persecution and violence under ISIL and during the anti-ISIL campaign has led many of the communities to mobilize their own forces since 2014, including tribal Sunni Arab, Ezidi, Turkmen, Shabak and Christian forces. Larger LHSFs such as the Peshmerga and the PMF seek to affiliate with these groups to take advantage of their local ties and knowledge, or to improve local legitimacy (Saadoun 2016, Salih 2015). Although often focused on local armed actors, Peshmerga and PMF forces have also attempted to co-opt local tribal or community leaders among both minority and Sunni Arab communities in Iraq's DIBs as they liberate them in order to extend control (Fantappie 2015; Jawoshy and Arango 2015).

The desire to manipulate, co-opt or control local forces in order to gain political influence is destabilizing local dynamics. Local leaders and communities are under significant pressure - either harassed and intimidated into supporting one side or another (Chapman 2016), or compelled to do so out of a pragmatic need for protection, access to services, and safe return for their communities (Fantappie 2015), van den Toorn and Mathieu-Comtois (2016) argue that the mobilization of different Ezidi militia groups in Sinjar, with loyalties to different political parties or geographic constituencies, is likely to increase conflict risks and instability locally (see also Salih 2015). Christian militias are similarly split along national-level partisan cleavages (Henderson 2014). Mansour (2016b) argues that internal divisions within the Sunni community as a whole, which have arguably increased with the competition for local allies in DIBs, increases the political marginalization and disengagement of the Sunni community as a whole, which has made it a less active partner against ISIL or other radical Sunni groups. 


\section{Displacement, Rule of Law and Governance Effects}

The cycles of conflict, and continuing competition between Baghdad and Erbil for the control of contested areas, have had significant socioeconomic and humanitarian consequences for local communities. Since 2014, fighting has led to mass displacement (IOM 2016) and significantly altered demographics across the DIBs, as well as within the Kurdistan Region of Iraq (KRI) (PAX 2016; USIP 2016), which is harboring large numbers of IDPs. Although far from the only factor, much of the displacement can be attributed to deliberate LHSF actions (Natali 2015; Puttick 2014; Hiltermann 2016; Fahim 2015; van den Toorn 2016b)

There has been little analysis so far on how the significant displacement, property loss, and other social and economic fallouts of communities across DIBs might affect local empowerment and participation in the near future, as this is still an open question. However, in the short term, control and policies applied by LHSFs may be preventing return and reconstruction. The United States Institute of Peace's (USIP) 2016 discussion of displaced communities' concerns and demands found that many IDPs do not return for fear of mass detentions and other LHSF abuses, or ongoing conflict between LHSFs, who are fighting over the control of some liberated areas (USIP 2016).

\section{Grassroots Solutions Going Forward}

The recent literature and ongoing policy discussions have stressed how fundamental these community legitimacy and trust questions are to future reconciliation and stability. USIP's study of rule of law and security dynamics among communities in recently liberated areas warned that, "[g]iven the mistrust between returning communities, their tendency to isolate themselves along religious lines (Muslim, Christian, Ezidi, Shabak, etc.), and the formation of religious-based militias, communities' readiness to embrace all types of extremist ideologies will likely increase” (USIP 2016). Van den Toorn and MathieuComtois' (2016) writing on Ezidi politics and Henderson's writing on Christian communities, offer similar warnings about how the fracturing of these communities and the lack of trust for those outside their communities encourages retaliation and cycles of conflict. Examining future Sunni political dynamics, Mansour (2016b) argues that retaliatory attacks and abuses by Shia PMF limit the chance of the Sunni community re-engaging with the Iraqi government or confronting ISIS, and thus contributing to the stability of Iraq in the future (see also Younis 2015, Vimont 2015). He argues that power-sharing guarantees to the Sunni community -- more local autonomy and security (via a national guard) -- and reining in other militias (such as the Shia PMF) would help prevent the continuation of dynamics that led to the rise of ISIL (Mansour 2016b).

As a result, ongoing political discussions in Iraq and among international partners frequently stressed the importance of local legitimacy and of developing bottom-up, grassroots solutions in response to emerging security, reconciliation, and reconstruction challenges (see El-Hamed, 2015; USIP 2016). On the security front, several have suggested that long-term stability will necessitate a greater level of community engagement and eventually empowering, for example, through a national guard that would include local Sunni forces in Sunni areas (Wehrey \& Ahram 2014; El-Hamed 2015). Similar discussions about maintaining minority communities' forces, but integrating them alongside state forces are ongoing, albeit not fully developed in the literature. For example, van den Toorn and Mathieu-Comtois 
(2016) suggest that because of the Ezidi desire for revenge, mistrust of both the Iraqi government and the KRG, and fears of exclusion, it is important for Ezidi forces to participate the protection of Ezidi areas, perhaps through affiliation or integration to the Peshmerga or the ISF.

More broadly, emerging discussions about reconstruction and reconciliation have paid significant attention to local grassroots interests. In a public panel discussion in July 2016, Christine van den Toorn highlighted these community tensions and argued that bottom-up, grassroots political compromise, to be achieved through dialogue at the local level, is the best way to avoid the resurgence of violence in post-ISIS areas. (Wilson Center Panel 2016, comments by van den Toorn). Practitioners have been developing strategies to better incorporate local buy-in to resolve immediate and mediumterm reconstruction challenges. For example, USIP recommended establishing joint security and administrative committees that include tribal and community elders to facilitate safe and equitable vetting and return policies (USIP 2016). While important for future study, there has so far been little literature on the effectiveness or feasibility of different grassroots and community empowerment strategies in addressing ongoing issues with LHSFs in Iraq.

\section{References}

ACAPS. 2014. Scenarios: Humanitarian Implications of Violence in Northern and Central Iraq. Geneva: ACAPS.

“After ISIS: Politics, Deal-Making, and the Struggle for Iraq’s Future.” 2016. Panel Discussion, Wilson Center, Washington, D.C., July 21. http://auis.edu.krd/events-calendar/auis-panel-discussion-wilsoncenter.

Aghuan, Ali. 2015. “The Popular Mobilization Forces’ Unfinished Mission” Fikra Forum View. Washington DC: Washington Institute.

Ali, Ahmed and Kimberly Kagan. 2014. "The Iraqi Shia Mobilization to Counter the ISIS Offensive.” Iraq Project Backgrounder Report. Washington DC: Institute for the Study of War

Al-Jawoshy, Omar and Tim Arango. 2015. "Iraqi Families Return to Fragile Stability in Tikrit After Liberation From ISIS.” The New York Times, June 23.

Amnesty International. 2014. Absolute Impunity: Militia Rule in Iraq. London: Amnesty International. Amnesty International. 2014a. Absolute Impunity: Militia Rule in Iraq. London: Amnesty International. Amnesty International. 2015a. Iraq: Barwana Massacre - Botched Investigation, Families Waiting for Justice. London: Amnesty International.

Amnesty International. 2015b. Iraq: Revenge attacks in Sinjar - Arab Civilians Pay the Price for IS Crimes. London: Amnesty International.

Amnesty International. 2016. Northern Iraq: Satellite images back up evidence of deliberate mass destruction in Peshmerga-controlled Arab villages. London: Amnesty International. 
Arango, Tim and Michael R. Gordon. 2016. “Turkey’s Push to Join Battle for Mosul Inflames Tension With Iraq.” The New York Times, October 23.

Beck, John. 2016. “Meet the PKK 'Terrorists' Battling the Islamic State on the Frontlines of Iraq.” Vice News, August 22.

Chapman, Chris. 2016. Improving Security for Minorities in Iraq. London, UK: Minority Rights Group International and Ceasefire Centre for Civilian Rights.

Chulov, Martin and Fazel Hawramy. 2014. "Iraq Crisis: Islamic State savagery exposes limits to Kurdish authority.” The Guardian, August 25.

Cigar, Norman. 2014. "Tribal Militias: An Effective Tool to Counter Al-Qaida and its Affiliates?” Strategic Studies Institute Report. Carlisle, PA: U.S. Army War College Press.

Cigar, Norman. 2015. "Iraq's Shia Warlords and their Militias: Political and Security Challenges and Options.” Strategic Studies Institute Report. Carlisle, PA: U.S. Army War College Press.

Coles, Isabel. 2015. “Iraqi Yazidis take revenge as Islamic State atrocities unearthed.” Reuters, February 10.

Davis, Eric. 2016. "State Sovereignty and Military Force in the Middle East: the Case of Iraq's PMUs." The New Middle East blog, September 30. http://new-middle-east.blogspot.com/2016/09/statesovereignty-and-military-in.html.

Dobbins, James et al. 2003. America’s Role in Nation-Building from Germany to Iraq. Santa Monica, CA: RAND.

El-Hamed, Raed. 2015. "Ramadi and the Debate Over Shia Militias in Anbar." Carnegie Sada. Washington DC: Carnegie Endowment for Peace.

Fahim, Kareem, 2015. "Shiite Militia Drives Back Islamic State, but Divides Much of Iraq." The New York Times, February 7.

Fantappie, Maria. 2015. “Arming Iraq’s Kurds: Fighting IS, Inviting Conflict.” Middle East Report 158. Brussels: International Crisis Group.

Fumerton, Mario and Wladimir Van Wilgenburg. 2015. "Kurdistan's Political Armies: The Challenge of Unifying the Peshmerga Forces.” Carnegie Regional Insight. Washington DC: Carnegie Endowment for International Peace.

Greenberg Quinlan Rosner Research. 2015. "Lack of Responsiveness Impacts Mood. August September 2015 Survey Findings.” The National Democratic Institute, 23 November.

Gulmohamad, Zana K. 2016. “Iraq's Shia Militias: Helping or Hindering the Fight Against Islamic State?” Terrorism Monitor 14: 9. 5-7. 
Gulmohamad, Zana. 2016b. "Unseating the Caliphate: Contrasting the Challenges of Liberating Fallujah and Mosul,” CTC Sentinel, https://www.ctc.usma.edu/posts/unseating-the-caliphate-contrasting-thechallenges-of-liberating-fallujah-and-mosul.

Habib, Mustafa. 2015. "Divided Loyalties: Iraq’s Controversial Shia Militias Fight among Themselves.” Niqash, June 18.

Henderson, Peter. 2014. "Iraq's Christian Paramilitaries Split in IS Fight," Al-Monitor, October 30. Hiltermann, Joost. 2016. “The Perils of a Post-ISIS Iraq. International Crisis Group.” Foreign Policy, September 22.

Hughes, Geraint and Christian Tripodi. 2009. "Anatomy of a Surrogate: Historical precedents and implications for contemporary counter-insurgency and counter-terrorism.” Small Wars \& Insurgencies 20:1.1-35.

Human Rights Watch. 2015a. "After Liberation Came Destruction. Iraqi Militias and the Aftermath of Amerli.” March 18.

Human Rights Watch. 2014b. "Iraq: Pro-Government Militias' Trail of Death. Attacks on Sunnis in At Least 3 Provinces.” July 31.

Human Rights Watch. 2015b. "Iraqi Kurdistan: Arabs Displaced, Cordoned Off, Detained Harsh Restrictions in Northern Iraq While Kurds Move Freely.” February 25.

Human Rights Watch. 2015c. "Iraqi Kurdistan: Release Peaceful Critic. Intelligence Forces Detain Critic Over Facebook Posts.” September 23.

Human Rights Watch. 2015d. "Ruinous Aftermath. Militia Abuses Following Iraq's Recapture of Tikrit," September 20.

Human Rights Watch. 2016a. "Iraq: Ethnic Fighting Endangers Civilians Kurds, Turkmen, Arabs Clash in Northern District.” January 13.

Human Rights Watch. 2016b. "Iraq: Possible War Crimes by Shia Militia. Sunnis Targeted in Muqdadiya after ISIS Attack.” February 1.

Human Rights Watch. 2016c. "Iraq: Fallujah Abuses Test Control of Militias. Investigate Government Command Responsibility; ISIS Stops Civilians From Fleeing.” June 9.

Human Rights Watch. 2016d. "President Obama Fails Child Soldiers. US Again Allows Military Aid to Countries Using Children as Fighters,” September 29.

Human Rights Watch. 2016e. "Marked with an 'X'. Iraqi Kurdish Forces' Destruction of Villages, Homes in Conflict with ISIS.” November 13.

International Organization for Migration. Displacement Tracking Matrix. http://iomiraq.net/dtmpage. 
Iraq Oil Report staff. 2015. “Multiple dead in Kurd-Hashid fight in Tuz,” November 13.

Kaválek, T. 2016. Yet Another Complication in Nineveh: Retaking Tal Afar, MERI Policy Brief. vol. 3, no. 17.

Knights, Michael. 2016. The Future of Iraq's Armed Forces. Baghdad: Al-Bayan Center Publication Series.

Mello, Alex and Michael Knights. (2016) "Losing Mosul, Regenerating in Diyala: How the Islamic State could exploit Iraq’s Sectarian Tinderbox,” CTC Sentinel.

Lake, David A. 2013. “Iraq: US approaches to statebuilding in the twenty-first century.” In The Routledge Handbook of International Statebuilding, edited by David Chandler and Timothy D. Sisk. 293303. New York, Routledge.

Mansour, Renad. 2016a. “The Popularity of the Hashd in Iraq.” Carnegie Diwan. Beirut: Carnegie Middle East Center.

Mansour, Renad. 2016b.The Sunni Predicament in Iraq. Beirut: Carnegie Middle East Center.

Mansour, Renad. 2016c. “Iraq: Battle Over Fallujah Test of Abadi's Leadership.” Al Jazeera, June 1.

McGeough, Paul. 2016. “The Struggle to Succeed Grand Ayatollah Ali Sistani.” Foreign Affairs, May 23.

Middle East Research Institute. 2016. Compliance of Armed Forces with International Humanitarian Law. MERI Policy Note. Erbil: Middle East Research Institute.

Mitchell, Neil J., Sabine C. Carey and Christopher K. Butler. 2014. "The Impact of Pro-Government Militias on Human Rights Violations.” International Interactions 40:5. 812-836.

Moar, Mark. 2015. “Iranian-backed Militias Endanger Iraq” FPI Bulletin. Washington DC: Foreign Policy Initiative.

Natali, Denise. 2015. “Counting on the Kurds.” Foreign Affairs, April 22.

Ned Parker. 2015. "Special Report: After Iraqi forces take Tikrit, a wave of looting and lynching," Reuters, April 3.

Ned Parker and Ahmed Rasheed. 2014. “Special Report: Inside Iraq's 'killing zones'," Reuters, December 17.

Pollack, Kenneth M. 2016a. “Iraq Situation Report, Part I: The military campaign against ISIS.” Brookings Markaz. Washington, DC: Brookings Institution.

Pollack, Kenneth M. 2016b. Iraq: A policy proposal for the next administration. Washington, DC: Brookings Institution.

Perito, Robert M. 2008. “Iraq's Interior Ministry: Frustrating Reform.” USIP Briefing. Washington DC: United States Institute of Peace. 
Puttick, Miriam. 2014. From Crisis to Catastrophe: the situation of minorities in Iraq. London, UK: Minority Rights Group International and Ceasefire Centre for Civilian Rights.

Rasheed, Ahmed and Michael Georgy. 2014. "After Victory in Key Iraqi Town, Time for Revenge,” Reuters, October 26.

Reuter, Christoph . 2016. “Deadly Hatred among Anti-IS Alliance in Iraq,” Der Speigel, June 1.

Reuters. 2016. "Iraq's traumatised Minorities: A test of unity after Mosul offensive," Thomson Reuters Foundation News, October 17.

Robinson, Linda. 2016. Assessment of the Politico-Military Campaign to Counter ISIL and Options for Adaptation. Santa Monica: RAND Corporation.

Rohwerder, Brigitte. 2014. "Contemporary Conflict Analysis of Iraq: Rapid literature review.” GSRDC Applied Knowledge Series.

Saadoun, Mustafa. 2016. “It’s Official: Sunnis joining Iraq's Popular Mobilization Units.” Al-Monitor, January 14.

Salama, Vivian and Qassim Abdul-Zahra. 2015. "Iraqi Militias Train Young Teens to Face the Threat of IS,” Associated Press, July 28.

Salih, Mohammed A. 2015. "With the Islamic State Gone from Sinjar, Kurdish Groups Battle for Control." Al-Monitor, December 10.

Serafino, Nina M., June S. Beittel, Lauren Ploch Blanchard, \& Liana Rosen, "Leahy Law Human Rights Provisions and Security Assistance: Issue Overview,” Congressional Research Service, January 29, 2014, http://fas.org/sgp/crs/row/R43361.pdf.

Smith, Samuel. 2016. "Sending Weapons to 'Christian Militias' in ISIS War in Iraq Is 'Bad Idea,' Chaldean Patriarch Warns.” Christian Post, May 25.

Stork, Joe. 2016. “Arm's Length Is still too Close for U.S. Troops and Abusive Iraqi Militias.” Military Times, July 9.

Sowell, Kirk H. 2016a. “After Ramadi, Militias in the Lead.” Carnegie Diwan. Beirut: Carnegie Middle East Center.

Sowell, Kirk H. 2015b. “The Rise of Iraq’s Militia State.” Carnegie Sada. Washington DC: Carnegie Endowment for Peace.

Sowell, Kirk H. 2015c. “Badr at the Forefront of Iraq's Shia Militias.” Carnegie Sada. Washington DC: Carnegie Endowment for Peace.

UNAMI/OHCHR. 2015. Report on the Protection of Civilians in the Armed Conflict in Iraq: 11 December 2014 - 30 April 2015. Baghdad: UNAMI. 
United States Department of State Bureau of Democracy, Human Rights and Labor, Iraq 2015 Human Rights Report, Country Reports on Human Rights Practices for 2015 (Washington DC: 2016)

van den Toorn, Christine. 2016a. "The Wars after the War for Sinjar: How Washington Can Avert a New Civil War," War on the Rocks, June 20.

van den Toorn, Christine. 2016b. “High Noon in Iraq’s Wild West,” Foreign Policy. February 22. van den Toorn, Christine and Sarah Mathieu-Comtois. 2016. Sinjar after ISIS: Returning to disputed territory. Utrecht: PAX for Peace.

van den Toorn, Christine and Shwan Lacky. 2014. "Shootout between 'allies” underscores Iraq's divisions," Iraq Oil Report, October.

Vimont, Pierre. 2015. “The Path to an Upgraded EU Foreign Policy.” Policy Outlook, June 30.

Wahab, Bilal. 2016. “Trouble Brewing in Iraqi Kurdistan.” Policy Analysis. Washington DC: The Washington Institute.

Wehrey, Frederic and Ariel I. Ahram. 2015. "Harnessing militia power: Lessons of the Iraqi National Guard.” Foreign Policy Essay. Washington DC: Lawfare Institute.

Wehrey Frederick and Ariel I. Ahram. 2014. "The National Guard in Iraq: A Risky Strategy to Combat the Islamic State.” Carnegie Endowment for International Peace, September 23.

Whiteside, Craig. 2016. “The Moral Hazard of the Fight Against the Islamic State in Iraq." War on the Rocks, February 22.

Wilke, Christoph. 2016. “Why Accountability for Iraq’s Militias Matters?” Just Security, May 27.

Williams, Sara Elizabeth. 2015. “Destroying Homes for Kurdistan” Foreign Policy, July 23.

Witty, David. 2016. The Iraqi Counter Terrorism Service. Washington DC: Center for Middle East Policy at Brookings.

Wood, Reed M., Jacob D. Kathman and Stephen E. Gent. 2012. “Armed Intervention and Civilian Victimization in Intrastate Conflicts.” Journal of Peace Research 49:5. 647-660.

Younis, Nussaibah. 2015. “A Cross-Sectarian Vision for Defeating the Islamic State in Iraq.” Beirut: Carnegie Middle East Center.

Young, Michael. 2015. "Use of Militias is a Bad Way to Run Foreign Policy,” The National (UAE), April 8. 


\section{Annex: Summary Table of Local, Regional or Sub-State Defense Forces in Iraq}

This background document provides a summary chart of the most significant and active regional, local, non-state or quasi-state forces in Iraq. This section will be organized based on the area of operation, with the groups that are active in Baghdad-controlled governorates and parts of the disputed territories first, such as Popular Mobilization Forces, followed by the groups active in areas controlled by the Kurdistan Regional Government (KRG) and parts of the disputed territories, such as the Peshmerga.

\section{Forces Operating in or Primarily Drawn from Baghdad-controlled Areas}

\begin{tabular}{|c|c|}
\hline $\begin{array}{l}\text { Popular Mobilization Forces (al- } \\
\text { Hashd al-Shaabi) }\end{array}$ & 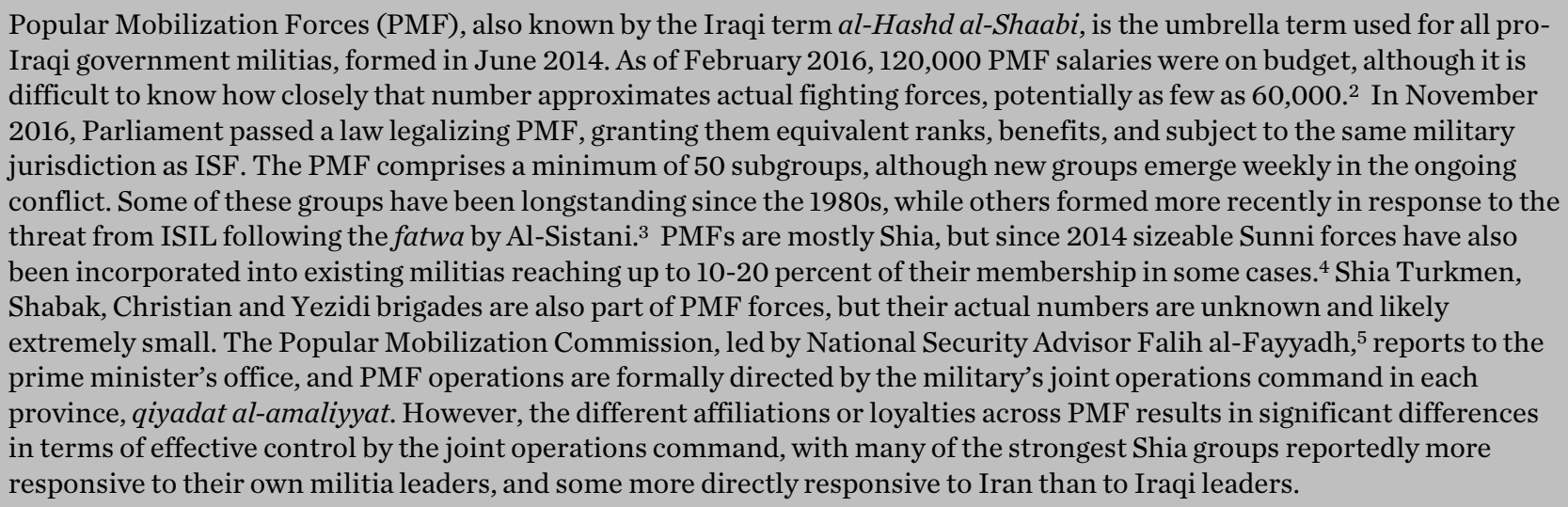 \\
\hline $\begin{array}{l}\text { Popular Mobilization Forces or } \\
\text { Units (PMF, PMU) (Al-Hashd al- } \\
\text { Shaabi) } \\
\text { Formed: } 2014 \\
\text { Strength: } 60,000-120,000 \text { estimated } \\
\text { Leader: multiple } \\
\text { Link to political party: } \mathrm{n} / \mathrm{a}\end{array}$ & $\begin{array}{l}\text { - Catch-all term for PMF volunteer forces under control of joint operations command (including some of those } \\
\text { described below) } \\
\text { - } \quad \text { Majority Shia but includes Sunni fighters as well }{ }^{6} \\
\text { - } \quad \text { Training by the MoD, recruitment through government-sponsored offices or those of religious foundations } \\
\text { - Includes Abbas Combat Division of the Abbasiyya Shrine (approx. 7,000); }{ }^{7} \text { Ali al-Akbar Brigades of the Hussayniyya } \\
\text { - Shrine (approx. 5,000); }{ }^{8} \text { First Martyr Movement/Free Iraqis; Turkmen Brigade } 17 \\
\text { Little information about their human rights record }\end{array}$ \\
\hline $\begin{array}{l}\text { Badr Organization (Munazzamah } \\
\text { Badr) } \\
\text { Formed: } 1983 \\
\text { Active: Yes } \\
\text { Strength: } \\
\text { Around } 20,000 \text { as of February } 2016^{10} \\
\text { Leader: Hadi Al-Ameri }\end{array}$ & $\begin{array}{l}\text { - Longest-standing and largest PMF, formed by Iraqi exiles in Iran during the } 1980 \text { s (as the "Badr Brigades") } \\
\text { Developed active political arm after the } 2003 \text { US invasion, and integrated into Iraqi government structures, despite } \\
\text { still significant ties to Iran } \\
\text { - Senior Badr member Mohammed Ghabban held the key post of minister of interior (federal police, intelligence) until } \\
\text { resigning in June } 2016^{11} \\
\text { - Famous military success in early victory over ISIL in Jurf al-Sakhar (Babel governorate) in } 2014\end{array}$ \\
\hline
\end{tabular}




\begin{tabular}{|c|c|}
\hline $\begin{array}{l}\text { Link to political party: Badr } \\
\text { Organization }\end{array}$ & $\begin{array}{l}\text { - Alleged HR violations in several operations (summary executions, kidnapping, arbitrary detention, torture, looting, } \\
\text { mass destruction of houses); for example, in Amerli, Muqdadiya, Sulaiman Bek, Tikrit and Tuz Khurmato }{ }^{12}\end{array}$ \\
\hline $\begin{array}{l}\text { League of the Righteous (Asa'ib Ahl } \\
\text { al-Haqq) } \\
\text { Formed: } 2006 \\
\text { Active: Yes } \\
\text { Strength: } 5,000-10,000 \text { as of March } \\
2015 \\
\text { Leader: Qais al-Khazali } \\
\text { Link to political party: Al-Sadiqun }\end{array}$ & $\begin{array}{l}\text { - Splinter group from the Mehdi Army (officially disbanded in 2008), with alleged close ties to former PM Nouri al- } \\
\text { Maliki and seen as the special operations unit of the PMF } \\
\text { - } \quad \text { Allegedly receives as much as } \$ 1.5-\$ 2 \mathrm{M} \text { a month from Iran }{ }^{13} \\
\text { - Several current or former commanders designated by US as global terrorists for attacks on US forces from 2006- } \\
\text { 2009;14 the organization designated as a terrorist group by UAE in } 2014 \\
\text { - Initially refused to participate in Tikrit operation in opposition to US involvement } \\
\text { - } \quad \text { Alleged HR violations in several operations (summary executions, kidnapping, arbitrary detention, torture, looting, } \\
\text { mass destruction of houses); for example, in Amerli, Muqdadiya, Sulaiman Bek, Tikrit, and Tuz Khurmato }{ }^{15} \\
\text { - Had a tiny locally based Sunni Arab contingent in al-Alam, Tikrit, }{ }^{16} \text { where HRW later alleged destruction by Sunni } \\
\text { - forces } \\
\text { - Reportedly receives additional income from criminal activities }{ }^{17}\end{array}$ \\
\hline $\begin{array}{l}\text { Hezbollah Brigades (Kata'ib Hizb } \\
\text { Allah) } \\
\text { Formed: } 2003 \\
\text { Active: Yes } \\
\text { Strength: } \\
\text { Around } 20,000 \text { as of February } 2016^{19} \\
\text { Leader: Jamal Jaafar Mohammed } \\
\text { (aka Abu Mahdi al-Muhandis) }\end{array}$ & $\begin{array}{l}\text { - Strongly supported via Iranian Revolutionary Guards and Lebanese Hezbollah for training and advice } \\
\text { Only PMF listed as a terrorist group by the US (since 2009), with the leader designated as global terrorist (since } \\
\text { 2009) } \\
\text { - } \begin{array}{l}{ }^{20} \\
\text { of oper of Hezbollah Brions }{ }^{21}\end{array} \\
\text { - Alleged HR violations in several operations (summary executions, kidnapping, arbitrary detention, torture, looting, } \\
\text { mass destruction of houses) - for example, in Amerli, Muqdadiya, Sulaiman Bek, Tikrit, and Tuz Khurmato }{ }^{22}\end{array}$ \\
\hline $\begin{array}{l}\text { Imam Ali Brigades (Kata'ib al-Imam } \\
\text { Ali) }{ }^{23} \\
\text { Formed: } 2014 \\
\text { Active: Yes } \\
\text { Strength: } \mathrm{n} / \mathrm{a} \\
\text { Leader: Shibl al-Zaydi } \\
\text { Link to political party: Harakat al- } \\
\text { Iraq al-Islamiyah }\end{array}$ & $\begin{array}{l}\text { - New, well-trained and equipped Iranian proxy militia with close links to Hezbollah Brigades and Iran's Quds Force. } \\
\text { - Abu Azrael, a commander, is a famous fighter that made waves in the media; }{ }^{24} \text { he was also praised by Sistani's office } \\
\text { - Trained two Christians units called Kataib Rouh Allah Issa Ibn Miriam Brigades and Babylon, as well as a Yazidi } \\
\text { group, the Sinjar brigade }{ }^{26}\end{array}$ \\
\hline $\begin{array}{l}\text { Khorasani Brigades (Saraya al- } \\
\text { Khorasani) } \\
\text { Formed: } 2013 \\
\text { Active: Yes } \\
\text { Strength: } 3,000 \text { as of February } 2015^{27} \\
\text { Leader: Ali al-Yasiri } \\
\text { Link to political party: } \mathrm{n} / \mathrm{a}\end{array}$ & $\begin{array}{l}\text { - Founded by an Iranian Arab commander with the IRGC's logo and named after the alias of Supreme Leader Ayatollah } \\
\text { Khamenei, this militia is the closest among the PMFs to Iran. } \\
\text { Allegedly, Iran sends all its training and logistical aid for all its PMF proxies through the Khorasani Brigades, whose } \\
\text { logistics center is in Qadir Kerem (Suleimaniyah governorate) on the road between Tuz Khormato and Iran }{ }^{28}\end{array}$ \\
\hline
\end{tabular}


Other active local, quasi- or nonstate security forces
There are several other significant forces operating in Baghdad-controlled areas or in the Disputed Territories that do not fit squarely into the PMF umbrella grouping, but may have significant overlaps, and joint fighting or cooperation. This includes tribal mobilization forces or Hashd al-Ashairi, which are sometimes considered the Sunni branch of the PMF and do come under ISF authority and receive ISF salaries. In practice, the degree of collaboration or integration with the PMU structure or select PMUs is not always clear, with leading Shia PMU organizations like Badr claiming to work with some of these tribal forces, ${ }^{29}$ but others appearing quite distinct from the PMU structure, if still coordinating and engaging in operations alongside PMU or ISF forces. Two other groups - the Peace Brigades and Hashd al-Watani - openly contest PMF leadership, and are considered to be illegal armed groups by some. They still may cooperate with other state or KRG forces on the ground, however, during operations.

- Collective term for tribal Sunni forces, under the nominal control of Falah al-Fayad, head of the National Security Agency and coordinating operations through joint operations command ${ }^{32}$

Tribal Mobilization Forces (Hashid al-Ashairi)

Formed: 2015

Active: Yes

Strength: 20,000 as of June 2016 in

Anbar; ${ }^{30} 15,000$ as of July 2016 in

Nineveh ${ }^{31}$ (real fighting forces might

be much lower)

Leader: Various.

Link to political party: Various

- Receive salaries through the Iraqi government, as with other PMF (though reported discrepancies in regularity of pay and weapons and equipment support)

- Operating primarily in Anbar, but recently also in Ninawa

- Initially proposed as a future Iraqi National Guard, and volunteers have signed up, but no ratification of the law establishing them ${ }^{33}$

- US provides light weapons and training for Sunni tribal forces in al-Habbaniya (Taqaddum) and Ain al-Assad air bases in Anbar ${ }^{34}$

- US-trained fighters were estimated to be $2,000-5,500$ fighters at the end of $2015,{ }^{35}$ but current estimates suggest as many as 35,000 authorized (20,000 in Anbar; 15,000 in Nineveh), although possibly not all trained and fighting ${ }^{36}$

- Little information about their human rights record

Peace Brigades (Saraya al-Salam)

Formed: 2014 (but formerly known as

Mahdi Army, 2003-2013)

Active: Yes

Strength: 14,000 as of July 2016 (but only 3,000 are registered under PMF salary $)^{37}$

Leader: Moqtada al-Sadr (but

military commander is Sayyid Riyad)

Link to political party: Sadrist trend, al-Ahrar bloc

\section{National Mobilization Forces}

(Al-Hashd al-Watani)

Formed: 2014

Active: Yes

Strength: approx. 4,000 to $6,000^{38}$

Leader: Atheel al-Nujaifi
- Nationalist-populist movement that draws support from poor Iraqi Shia and opposes Iranian interpretation of Wilayat al-Faqih

- Supports the integration of militias into the state and contests control by PMF leadership

- Hakim al-Zamili (al-Ahrar) is head of parliamentary committee on security and defense

- Impact on national politics through protests

- Little information about their human rights record, but temporarily froze operations in February 2015 after allegations of mass destruction of houses in Amerli 
Link to political party: al-

Muttahidun
- where Turkish military forces are training them. Many of them receive their salary from Turkey. Al-Nujaifi opposes the PMF's participation in the Mosul operation. The role of his militia is unclear as the federal government, the PMF, and some of the Hashd al-'Asha'iri do not view Turkey-sponsored Hashd al-Watani as a legitimate force unless it submits to Iraq's National Security Agency's authority ${ }^{42}$

\section{Forces Primarily Operating in and drawn from KRG-controlled areas}

\begin{tabular}{|c|c|}
\hline Peshmerga Forces & $\begin{array}{l}\text { With an estimated } 190,000 \text { to } 250,000 \text { fighters, the Peshmerga is the largest active force in the Kurdistan Region of } \\
\text { Iraq and the Disputed Territories (although significant numbers of ghost forces estimated). }{ }^{43} \text { The Peshmerga's level } \\
\text { of command, control and organization puts it closer to a state force. The Peshmerga comprise different types of } \\
\text { security forces - including military, police, intelligence, minority brigades, private militias - that break down along } \\
\text { party lines and report to the leadership of the Kurdish Democratic Party (KDP) and the Patriotic Union of } \\
\text { Kurdistan (PUK). Aside from party-commanded forces, there is a nominally independent, integrated Peshmerga } \\
\text { force of } 14 \text { brigades, the Regional Guard Brigades, which have split command between the KDP and the PUK, and } \\
\text { formally fall under the command of the Ministry of Peshmerga Affairs. Minorities, including Sunni Arabs, } \\
\text { Christians and Yazidis can and do join the Peshmerga as soldiers, and some have formed minority brigades within } \\
\text { the Peshmerga. }\end{array}$ \\
\hline $\begin{array}{l}\text { Regional Guard Brigades } \\
\text { Formed: } 2010 \\
\text { Active: Yes } \\
\text { Strength: } 14 \text { Regional Guard Brigades, } \\
\text { approx. } 40,000^{44} \\
\text { Leaders: KRG President Masoud Barzani } \\
\text { and KRG Ministry of Peshmerga Affairs } \\
\text { (formally); PUK and KDP political leaders } \\
\text { (de facto) }\end{array}$ & $\begin{array}{l}\text { - Integrated Peshmerga under Ministry of Peshmerga Affairs, but de facto under PUK and KDP party control } \\
\text { - Leadership positions distributed along 50-50 principles: brigades headed by KDP commanders have PUK } \\
\text { deputy commanders, and vice versa } \\
\text { Training provided at KTCC sites by a 9-member coalition (Italy, Germany, Hungary, Italy, the Netherlands, } \\
\text { Norway, Finland, the United Kingdom, Slovenia, and Turkey), with weapons and equipment provided by the } \\
\text { United States } \\
\text { Implicated in ethnic “clearing” policies - preventing the return of Arab communities once an areas has been } \\
\text { cleared of ISIL. These allegations have sometimes risen to the level of ethnic cleansing. }\end{array}$ \\
\hline $\begin{array}{l}\text { KDP-commanded Peshmerga Division } 80 \\
\text { Formed: } 1970 \text { s } \\
\text { Active: Yes } \\
\text { Strength: approx. 50,000 fighters } \\
\text { Leaders: KRG President and KDP leader } \\
\text { Masoud Barzani (formally and de facto) }\end{array}$ & $\begin{array}{l}\text { - KDP affiliated Peshmerga units divided among regular units (Division 80), Zerevani (which fall under the } \\
\text { - } \quad \text { PRG MoI), and counter-terrorism forces } \\
\text { - } \quad \text { Reportedly receive Turkish support, including training at Bashiqa air base near Mosul } \\
\text { - Implicated in ethnic "clearing" policies - preventing the return of Arab communities once an areas has been } \\
\text { cleared of ISIL. These allegations have sometimes risen to the level of ethnic cleansing. }\end{array}$ \\
\hline $\begin{array}{l}\text { PUK-commanded Peshmerga } \\
\text { Formed: } 1970 \text { s } \\
\text { Active: Yes } \\
\text { Strength: approx. } 48,000 \text { fighters }\end{array}$ & $\begin{array}{l}\text { - } \quad \text { PUK affiliated units typically divided according to regular units (Division 70) and Deja Terror (Counter- } \\
\text { terrorism Forces) } \\
\text { - } \quad \text { Operate in PUK zones of control: (eastern half of Iraqi Kurdistan), Kirkuk, and Sinjar } \\
\text { - } \quad \text { Reportedly receive some support from Iran but unclear in what form }\end{array}$ \\
\hline
\end{tabular}


Leader: KRG President Masoud Barzani

(formally); PUK SG Jalal Talabani (de facto)

Local or non-state forces affiliated with

the Peshmerga

Yazidi Peshmerga

Formed: 2014

Active: Yes

Strength: ca. 10,000 fighters $^{45}$

Leader: Qasim Shesho

\section{Rojava Peshmerga}

Formed: 2014

Active: Yes

Strength: 3,000-6,000 fighters ${ }^{46}$

Leader: Brig. Gen. Mohammed Rejeb Dehdo

Nineveh Plains Force (NPF)

Formed: 2014

Active: ?

Strength: reportedly approx. 500 as of July $2015^{50}$

Leader: Romeo Hakari

\section{Dwekh Nawsha}

Formed: 2014

Active: yes

Strength: approx. 100 as of July 2015

Leader: Lt. Col. Odisho

\section{Other local or non-state groups}

- $\quad$ Active in front-line combat against ISIL

- Implicated in ethnic "clearing" policies - preventing the return of Arab communities once an areas has been cleared of ISIL. These allegations have sometimes risen to the level of ethnic cleansing.

A number of minority groups have set up militias under the Peshmerga, including Shabak, Kakai, Yazidis and Christians. There is generally little information available about these groups and their conduct in war.

- A Yazidi brigade allied with the Peshmerga

- Active in Sinjar

- $\quad$ Consist of Syrian Kurdish soldiers who fled the Syrian Army (but disagree with YPG/YPJ) ${ }^{47}$

- Training by the Zeravani forces ${ }^{48}$ and reportedly possible training by Turkey

- Intra-Kurdish differences prevent the militia from returning to Syria; hence, they fight ISIL in Iraq ${ }^{49}$

- Active mostly on southern fronts, Mosul and Kirkuk, and Syrian border near Sinjar and Rabia

- $\quad$ One of the two pro-KRG Assyrian Christian militias in Iraq

- $\quad$ Equipment and training by the Peshmerga ${ }^{51}$

- Linked to Bet-Nahrain Democratic Party

- Operating north of Mosul

- All-volunteer force linked to the Assyrian Patriotic Party

- Trained and equipped by Peshmerga

- Operating northwest of Mosul

- Troops wear Zerevani badges ${ }^{52}$

A number of local or non-state forces operate independently from the Peshmerga in areas formally controlled by the KRG, most notably, the Kurdistan Worker's Party (PKK) and its affiliates. Others are semi-independent militias in continuous talks about joining the Peshmerga and/or the Iraqi Security Forces, for example, the Yazidi Ezidkhan Protection Force (Heza Parastina Ezidxane, or HPE). ${ }^{53}$ Finally, one pro-Baghdad group is also worth mentioning: the Nineveh Plains Protection Units. This is the armed wing of the Assyrian Democratic Movement, which is one of the two largest Iraqi Christian parties. Unlike its main rival, the pro-KRG Chaldean Syriac Assyrian Popular Council, the Assyrian Democratic Movement promotes Baghdad's claim over the disputed territories and the Nineveh Plains in particular. Therefore, the Nineveh Plains Protection Units is wary of the Peshmerga who in turn do not allow this pro-Baghdad militia to join the frontline of the fight against ISIL. ${ }^{54}$ 
People's Defense Forces (Hêzen Parastina Gel, HPG)

Formed: 1984 (PKK formed in 1978)

Active: Yes

Strength: 7,000-10,000 troops ${ }^{55}$

Leader: Murat Karayilan (de facto PKK

leader since 1999 and commander in chief of

HPG)

People's Defense For

Parastina Gel, YPG)

Active: Yes

Leader: Nasreen Abdullah and Cihan

Cendal

Sinjar Resistance Units (Yekîneyên

Berxwedana Şengalê, YBS)

Formed: 2015

Active: Yes

Strength: $1,500-2,000$ as of $2014^{58}$

Leader: Khider Salih, head of the

Autonomous Administrative Council, the

political wing of YBS

Protection Force of Ezidxan (Hêzen

Parastina Êzîdxanê, HPE)

Formed: 2015

Active: Yes

Strength: 2,500 trained fighters (approx.

8,000 associated with the group)

Leader: Haider Shesho

\section{Nineveh Plains Protection Unit}

Formed: 1980s (with different name)

Active: Yes

Strength: approx. 3,000 forces as of

February $2015^{63}$

Leaders: Gen. Behnam
- $\quad$ Armed wing of PKK leading struggle for Kurdish autonomy in Turkey

- HQ in Qandil mountains (PUK zone of control) but only began active combat operations in Iraq (Sinjar and Makhmour) in August 2014, where it was credited for important anti-ISIL military successes

- Iran provides covert logistical and financial support according to Turkish intelligence, ${ }^{56}$ but otherwise largely self-supported (reportedly with criminal activities and trafficking) ${ }^{57}$

- In April 2016, PKK offered to contribute 4,000 fighters to the Mosul operation, pending Iraqi government approval

- $\quad$ Listed as a terrorist organization by Turkey, NATO, the United States, and the EU. The UN and other countries such as Switzerland, China, India, Russia and Egypt do not consider it to be a terrorist organization

- $\quad$ Reported human rights violations, including forced recruitment

- Armed wing of the PYD leading the struggle for Kurdish autonomy in Syria

- While disputed, branch of the PKK and HPG

- $\quad$ Came to the rescue of Yezidis when they were trapped on Mt. Sinjar after ISIL attacked August $3^{\text {rd }}, 2014$

- Supported by the US and Coalition forces in the fight against ISIL in Syria

- $\quad$ Founded by PKK and the YPG who continue to provide some military training and logistical support. ${ }^{59}$

- Iraqi Central Government provides financial support, paying the salaries of 1,000 fighters ${ }^{60}$ Often portrayed as PKK-tool, but its leader argues the PKK does not control them ${ }^{61}$

- Mostly Yazidi membership

- Has a female equivalent, the Ezidxan Women's Units (Yekinêyen Jinên Êzidxan, YJE), led by Da Shiereen Saleh (formerly known as Sinjar Women's Protection Units

- Yazidi forces with frequently changing allegiances, most recently paid by Baghdad as part of PMF

- Active in Sinjar, mainly in the northern portions as of June 2016,62 military base near Sherefedin

- $\quad$ Formerly known as Sinjar Protection Forces (Hêzen Parastina Shingal, HPS) 
${ }^{1}$ There is also a much deeper academic literature addressing the advantages of militias in countries including but not limited to Iraq. Seth Jones has argued that militias historically have advantages in terms of intelligence gathering, reporting on insurgent activity, and "protecting and governing the population." Seth Jones, Strategic Logic of Militias (RAND: 2012) p. 16-17, available at https://www.rand.org/content/dam/rand/pubs/working_papers/2012/RAND_WR913.pdf. Stathis N. Kalyvas has found that militias can play an important role in counterinsurgency because they can hold local areas, are effective against rebels, and relatively easy to form and recruit, and offer advantages in intelligence gathering. Stathis N. Kalyvas, The Logic of Violence in Civil War (Cambridge University Press: 2006), p. 108. Goran Peic found that

"incumbents" (state forces) are significantly more likely to defeat insurgents when they deploy militias. Goran Peic Civilian Defense Forces, State Capacity, and

Government Victory in Counterinsurgency Wars, 2014, Studies in Conflict \& Terrorism, 37:2, 162-184.

${ }^{2}$ Knight, M. (2016). "Iraq's Popular Demobilization." AL-Jazeera English. URL: http://www.aljazeera.com/indepth/opinion/2016/02/iraq-popular-demobilisation160224050939178.html

Knight, M. (2016). “The Future of Iraqi Armed Forces.” Al-Bayan Center for Planning and Studies. URL: http://www.aljazeera.com/indepth/opinion/2016/02/iraqpopular-demobilisation-160224050939178.html

${ }^{3}$ Of the approximately 120,000 on budget, approximately 60.000 are estimated to have pre-existed the 2014 crisis, whereas 40,000 have been organized since 2014

(Ibid.)

${ }^{4}$ Factions supported by the Ataba have a higher percentage of Sunni fighters: Ali al-Akbar Brigade has 20\% Sunnis; Abbas Combat Division has $10 \%$ Sunnis

Tollast, R. (2016). "Inside Iraq's Popular Mobilization Units.” The National Institute. URL: http://nationalinterest.org/feature/iraqs-shia-militias-arent-bad-you-think16291?page=2;

${ }^{5}$ For his profile, see: ASHARQ AL-AWSAT. (2016). “"فاح فياض قوته في صمتهاح" Issue, 13886.

URL:http://aawsat.com/home/article/422371/\%D9\%81\%D8\%A7\%D9\%84\%D8\%AD-\%D8\%A7\%D9\%84\%D9\%81\%D9\%8A\%D8\%A7\%D8\%B6-

\%D9\%82\%D9\%88\%D8\%AA\%D9\%87-\%D9\%81\%D9\%8A-\%D8\%B5\%D9\%85\%D8\%AA\%D9\%87

${ }^{6}$ ORSAM. (2015). “A New Controversial Actors in Post-ISIS Iraq: Al-Hashd Al-Shaabi (The Popular Mobalization Forces).” URL:

http://www.orsam.org.tr/files/Raporlar/rapor198/198eng.pdf

${ }^{7}$ Steele, J. (2015). “Sunni Tribes Joining Shia Militias as War against IS Heats Up in Iraq.” Middle East Eye. URL:

http://www.middleeasteye.net/news/sunni-tribes-joining-shia-militias-war-against-heats-iraq-1175770052

${ }^{8}$ Tastekn, F. (2015). “Three Faiths, Three Commanders.” Al-monitor. URL: http://www.al-monitor.com/pulse/originals/2016/01/turkey-iraq-three-commandersthree-faiths.html

${ }^{9}$ http://www.counterextremism.com/threat/badr-organization; http://foreignpolicy.com/2014/11/06/breaking-badr

${ }^{10}$ Knight, M. (2016). “Iraq’s Popular Demobilization.” Al-Jazeera English. URL: http://www.aljazeera.com/indepth/opinion/2016/02/iraq-popular-demobilisation160224050939178.html

${ }^{11}$ Morris, L. (2014). “Appointment of Iraq’s New Interior Minister Opens Door to Militia and Iranian Influence.” The Washington Post. URL:

https://www.washingtonpost.com/world/appointment-of-iraqs-new-interior-minister-opens-door-to-militia-and-iranian-influence/2014/10/18/f6f2a347-d38c4743-902a-254al69ca274_story.html

${ }^{12}$ Human Rights Watch (2016). “Iraq: Ethnic Fighting Endangers Civilians Kurds, Turkmen, Arabs Clash in Northern District.” URL:

https://www.hrw.org/news/2016/01/13/iraq-ethnic-fighting-endangers-civilians; Human Rights Watch (2016). "Iraq: Ethnic Fighting Endangers Civilians Kurds,

Turkmen, Arabs Clash in Northern District.” URL: https://www.hrw.org/news/2016/01/13/iraq-ethnic-fighting-endangers-civilians; Human Rights Watch (2016).

"Ruinous Aftermath. Militias Abuses Following Iraq's Recapture of Tikrit,”URL: https://www.hrw.org/report/2015/09/20/ruinous-aftermath/militias-abuses-

following-iraqs-recapture-tikrit

${ }^{13}$ Chulov, M. (2014). “Controlled by Iraq, the Deadly Militias Recruit Iraq’s Men to Die n Syria.” The Guardian. URL:

https://www.theguardian.com/world/2014/mar/12/iraq-battle-dead-valley-peace-syria 
${ }^{14} \mathrm{Abu}$ Dura, and Mustafa al Sheibani were added to the US global terrorist lists in January 2008, and are reported to have returned to Iraq and implicitly re-engaged. A number of other former leaders or commanders from the League of the Righteous were also added to the US global terrorist list for their coordination of or engagement in attacks against US forces from 2006 to 2009, but it is unclear if some of these other commanders have re-engaged with the League of the Righteous in current operations.

Roggio, B. (2014). “US Airstrikes in Amerli Supported Deadly Shia Group.” Long War Journal. URL

http://www.longwarjournal.org/archives/2014/09/us_airstrikes_in_ame.php

${ }^{15}$ Human Rights Watch (2016). “Iraq: Ethnic Fighting Endangers Civilians Kurds, Turkmen, Arabs Clash in Northern District.” URL:

https://www.hrw.org/news/2016/01/13/iraq-ethnic-fighting-endangers-civilians; Human Rights Watch (2016). "Iraq: Ethnic Fighting Endangers Civilians Kurds,

Turkmen, Arabs Clash in Northern District.” URL: https:/ www.hrw.org/news/2016/01/13/iraq-ethnic-fighting-endangers-civilians; Human Rights Watch (2016).

"Ruinous Aftermath. Militias Abuses Following Iraq's Recapture of Tikrit,"URL: https://www.hrw.org/report/2015/09/20/ruinous-aftermath/militias-abuses-

following-iraqs-recapture-tikrit

${ }^{16}$ W.G, D. (2015). “Iraqi Sunnis Joined Feared Shia Militias to Fight IS.” Yahoo News. URL: https://www.yahoo.com/news/iraqi-sunnis-join-feared-shiite-militia-

battle-213921399.html?ref=gs

${ }^{17}$ Al-Shibeeb, D. (2015). “Iraqi Tribes Ready to Join Anti-ISIS Volunteer Forces, Says PMU Official.” Al-Arabia English. URL:

http://english.alarabiya.net/en/perspective/profiles/2015/09/28/Iraqi-tribes-ready-to-join-anti-ISIS-volunteer-forces-says-PMU-official-.html

${ }^{18}$ Dehghanpisheh, B. (2014). Special Report: The Fighters of Iraq Who Answer to Iran. Reuters. URL:http://www.reuters.com/article/us-mideast-crisis-militiasspecialreport-idUSKCNOIWOZA20141112

${ }^{19}$ Knight, M. (2016). “Iraq’s Popular Demobilization.” Al-Jazeera English. URL: http://www.aljazeera.com/indepth/opinion/2016/02/iraq-popular-demobilisation160224050939178.html

${ }^{20}$ U.S Department of Treasury. (2009). Treasury Designates Individual, Entity Posing Threat to Stability in Iraq. URL:

https://www.treasury.gov/press-center/press-releases/Pages/tg195.aspx

U.S Department of State. (2009). Designation of Kata'ib Hizballah as a Foreign Terrorist Organization. URL: http://www.state.gov/r/pa/prs/ps/2009/july/125582.htm

${ }^{21}$ Malas, N. (2016). "The Militia Commander Beating Back ISIS in Iraq Makes the U.S. Nervous." Wall Street Journal. URL:

http://www.wsj.com/articles/the-militia-commander-beating-back-isis-in-iraq-makes-the-u-s-nervous-1464890675

${ }^{22}$ Human Rights Watch (2016). “Iraq: Ethnic Fighting Endangers Civilians Kurds, Turkmen, Arabs Clash in Northern District.” URL:

https://www.hrw.org/news/2016/01/13/iraq-ethnic-fighting-endangers-civilians; Human Rights Watch (2016). "Iraq: Ethnic Fighting Endangers Civilians Kurds,

Turkmen, Arabs Clash in Northern District.” URL: https://www.hrw.org/news/2016/01/13/iraq-ethnic-fighting-endangers-civilians; Human Rights Watch (2016).

"Ruinous Aftermath. Militias Abuses Following Iraq's Recapture of Tikrit,” URL: https://www.hrw.org/report/2015/09/20/ruinous-aftermath/militias-abuses-

following-iraqs-recapture-tikrit

${ }^{23}$ Livett, M. and Symth. Ph. (2015). Kataib al-Imam Ali: Portrait of an Iraqi Shiite Militant Group Fighting ISIS. The Washington Institute.” URL:

http://www.washingtoninstitute.org/policy-analysis/view/kataib-al-imam-ali-portrait-of-an-iraqi-shiite-militant-group-fighting-isis

${ }^{24}$ BBC Trending. (2015). The Archangel of Death' fighting Islamic State.” URL: http://www.bbc.com/news/blogs-trending-31913278

${ }^{25}$ Spencer, R. (2014). «Iraqi Shia Militia Who Fought Isil Condemned for Revenge Beheadings.” The Telegraph. URL

http://www.telegraph.co.uk/news/worldnews/middleeast/iraq/11087584/Iraqi-Shia-militia-who-fought-Isil-condemned-for-revenge-beheadings.html; AL-

JAZEERA. (2015). "Video Purports to Show Militia Atrocity in Iraq.” URL: http://www.aljazeera.com/news/2015/05/video-purports-show-militia-atrocity-iraq$150531150815036 . \mathrm{html}$

${ }^{26}$ Livett, M. and Symth. Ph. (2015). Kataib al-Imam Ali: Portrait of an Iraqi Shiite Militant Group Fighting ISIS. The Washington Institute." URL:

http://www.washingtoninstitute.org/policy-analysis/view/kataib-al-imam-ali-portrait-of-an-iraqi-shiite-militant-group-fighting-isis; Dina al-Shibeeb, "Iraqi tribes ready to join anti-ISIS volunteer forces, says PMU official," Al-Arabbiya news, 28 September 2015, URL:

http://english.alarabiya.net/en/perspective/profiles/2015/09/28/Iraqi-tribes-ready-to-join-anti-ISIS-volunteer-forces-says-PMU-official-.html

${ }^{27}$ Parker, N. et al. (2015). “How Iran's Military Chief Operates in Iraq.” Reuters. URL: http://www.reuters.com/investigates/special-report/mideast-crisis-committee/

${ }^{28}$ ORSAM. (2015). A New Controversial Actors in Post-ISIS Iraq: Al-Hashd Al-Shaabi (The Popular Mobalization Forces). URL

http://www.orsam.org.tr/files/Raporlar/rapofilo8/98eng.pdfAFT WORKING PAPER: NOT FOR DISTRIBUTION OR CITATION 
${ }^{29}$ Dina Al-Shibeeb, “Iraqi tribes ready to join anti-ISIS volunteer forces, says PMU official," 28 September 2015, Al Arabiya News,

http://english.alarabiya.net/en/perspective/profiles/2015/09/28/Iraqi-tribes-ready-to-join-anti-ISIS-volunteer-forces-says-PMU-official-.html; Alex Mello and Michael Knights, “Losing Mosul, Regenerating in Diyala: How the Islamic State could exploit Iraq's Sectarian Tinderbox,” CTC Sentinel, 26 October 2016, (noting that "Jabbouri confederation Hashd al-Asha'ir fighters work with Badr in northern Diyala, as they do in the Tikrit and Kirkuk areas").

${ }^{30}$ Embassy of the United States. (2016). Special Presidential Envoy Brett McGurk in Iraq. URL:

http://iraq.usembassy.gov/pr-062116.html

${ }^{31}$ Kurdistani, A. (2016). "Why Sunnis Don’t Want Shiite Militia in the Mosul Offensive." Rudaw. URL:

http://rudaw.net/english/middleeast/iraq/01072016

${ }^{32}$ Zana Gulmohamad, "Unseating the Caliphate: Contrasting the Challenges of Liberating Fallujah and Mosul," CTC Sentinel, 17 October 2016,

https://www.ctc.usma.edu/posts/unseating-the-caliphate-contrasting-the-challenges-of-liberating-fallujah-and-mosul.

${ }^{33}$ A Kuridstani (2014). "Why Iraq's New National Guard Has Nothing Left to Lose.” Niqash. URL:http://www.niqash.org/en/articles/security/3546/

${ }^{34} \mathrm{http}: / /$ www.wsj.com/articles/iraq-begins-training-of-sunni-tribal-fighters-1431302014; http://www.aljazeera.com/news/2015/07/defence-secretary-carter-

surprise-trip-iraq-150723092107679.html.

${ }^{35}$ Estimates on Sunnis trained by the US. 2000 as of December 2015 according to PMF.

" Daily Motion. 16:38. Posted by Yerin Dolmuyor. December 2015. URL: PMF

http://www.dailymotion.com/video/x3jcssv. In June 2015, trained and equipped Iraqi Sunnis in Anbar numbered 5.500 and the target was to reach 10.000. Gordon, M. and Davis, J. (2015). “In Shift, U.S. Will Send 450 Advisers to Help Iraq Fight ISI.” The New York Times. URL:

http://www.nytimes.com/2015/06/11/world/middleeast/us-embracing-a-new-approach-on-battling-isis-in-iraq.html?_r=0; or 4.400 as of January 2016 according to

Al-Monitor. M. (2016). "It's official: Sunnis joining Iraq's Popular Mobilization Units." Al-Monitor. http://www.al-monitor.com/pulse/originals/2016/01/iraq-sunnisjoin-shiite-popular-mobilization-forces.html

${ }^{36}$ Embassy of the United States. (2016). Special Presidential Envoy Brett McGurk in Iraq. URL:

http://iraq.usembassy.gov/pr-062116.html. Kurdistani, A. (2016). “Why Sunnis Don’t Want Shiite Militia in the Mosul Offensive.” Rudaw. URL:

http://rudaw.net/english/middleeast/iraq/01072016; https://www.ctc.usma.edu/posts/unseating-the-caliphate-contrasting-the-challenges-of-liberating-fallujahand-mosul

${ }^{37}$ Ibid.

${ }^{38}$ Zana Gulmohamad, "Unseating the Caliphate: Contrasting the Challenges of Liberating Fallujah and Mosul," CTC Sentinel, 17 October 2016,

https://www.ctc.usma.edu/posts/unseating-the-caliphate-contrasting-the-challenges-of-liberating-fallujah-and-mosul.

${ }^{39}$ Zana Gulmohamad, "Unseating the Caliphate: Contrasting the Challenges of Liberating Fallujah and Mosul," CTC Sentinel, 17 October 2016,

https://www.ctc.usma.edu/posts/unseating-the-caliphate-contrasting-the-challenges-of-liberating-fallujah-and-mosul.

${ }^{40}$ Zeidel, R. and Sagnic, C. (2015). “The Politics of the Turkish Military Presence near Mosul.” Television Notes. Vol 9. URL:

www.dayan.org/file/17864/download?token=x4otfH3N

41 "Sunni militia to come under Peshmerga command for Mosul operation,” Rudaw, October 5, 2016. "Under ISIS fire, Sunni military base readies for Mosul offensive,"

Rudaw, March 29, 2016.

${ }^{42}$ Zana Gulmohamad, “Unseating the Caliphate: Contrasting the Challenges of Liberating Fallujah and Mosul,” CTC Sentinel, 17 October 2016, FN 93,

https://www.ctc.usma.edu/posts/unseating-the-caliphate-contrasting-the-challenges-of-liberating-fallujah-and-mosul; "Report: Iraq's al-Hashd al-Watani forces;

troublemaker for Mosul liberation?” Alwaght, June 21, 2016

${ }^{43}$ Hawramy, F. (2014). “Kurdish Peshmerga Divisions Hamper War Effort.” Al-Monitor. URL:

http://www.al-monitor.com/pulse/originals/2015/01/iraq-kurdish-peshmerga-division-islamic-state.html

${ }^{44}$ Van Wilgenburg, W. and Fumerton, M. (2015). “Kurdistan’s Political Armies. The Challenges of Unifying Peshmerga Forces.” Carnegie Endowment for International Peace. URL: http://carnegieendowment.org/2015/12/16/kurdistan-s-political-armies-challenge-of-unifying-peshmerga-forces-pub-61917

${ }^{45}$ Van den Toorn, C. (2016). "The Wars after the War for Sinjar. How Washington Can Avert a New Civil War.” War on the Rocks. URL:

http://warontherocks.com/2016/06/the-wars-after-the-war-for-sinjar-how-washington-can-avert-a-new-civil-war/ 
Salih, M. (2015). "With the Islamic State Gone from Sinjar, Kurdish Groups Battle for Control.” Al-monitor. URL: http://www.almonitor.com/pulse/originals/2015/12/iraq-kurdistan-sinjar-liberated-isis-hegemony.html

${ }^{46}$ Arafat, H. (2016). "Syrian Kurdish women join Peshmerga.” Kurdistan. URL: http://www.kurdistan24.net/en/sport/75952338-772a-453d-bef6-24b82aladf72/SyrianKurdish-women-join-Peshmerga

${ }^{47}$ Ibid.

${ }^{48}$ Igantius, D. (2016). “How the Kurds’ Neighbors Play Games to Block the Expansion of 'Greater Kurdistan.” The Washington Post.

URL:https://www.washingtonpost.com/blogs/post-partisan/wp/2016/05/27/kurdish-factions/

${ }^{49}$ IgantiUs, D. (2016). “How the Kurds' Neighbors Play Games to Block the Expansion of ‘Greater Kurdistan.” The Washington Post.

URL:https:/www.washingtonpost.com/blogs/post-partisan/wp/2016/05/27/kurdish-factions/

${ }^{50}$ Matt-Cetti, R. (2015). “Inside the Christian Militias Defending the Nineveh Plains: Some Work with the Peshmerga, Some Don't-and They Only Trust Their Own."

War is Boring. URL:https://warisboring.com/inside-the-christian-militias-defending-the-nineveh-plains-fe4alobabeed\#.7uusgoklr

Salih, M. (2015). "With the Islamic State Gone from Sinjar, Kurdish Groups Battle for Control." Al-monitor. URL: http://www.al-

monitor.com/pulse/originals/2015/12/iraq-kurdistan-sinjar-liberated-isis-hegemony.html

${ }^{51}$ Matt-Cetti, R. (2015). “Inside the Christian Militias Defending the Nineveh Plains: Some Work with the Peshmerga, Some Don't-and They Only Trust Their Own."

War is Boring. URL:https://warisboring.com/inside-the-christian-militias-defending-the-nineveh-plains-fe4alobabeed\#.7uusgoklr

${ }^{52}$ Henderson, P. (2014). "Iraq's Christian Paramilitaries Split in IS fight." Al-Monitor. URL: http://www.al-monitor.com/pulse/originals/2014/10/iraq-christianparamilitary-forces-nineveh.html

${ }^{53}$ Ibid.

${ }^{54}$ Matt-Cetti, R. (2015). “Inside the Christian Militias Defending the Nineveh Plains: Some Work with the Peshmerga, Some Don’t-and They Only Trust Their Own.”

War is Boring. URL:https://warisboring.com/inside-the-christian-militias-defending-the-nineveh-plains-fe4alobabeed\#.7uusgoklr

${ }^{55}$ 5,000 fighters in Sinjar area and hundreds more along the Makhmour frontline, as of April 2016. An additional 3,500 troops in Turkey (Nusaybin area), as of 2013.

Approx. 300 fighters in northern Syria, mainly Kobane (Ayn al-Arab), Derik (Al-Malikiyah), and Afrin regions.

Radio Free Radio Liberty. (2013). Facts And Figures: Kurdistan Workers Party. URL:http://www.rferl.org/content/profile-history-pkk-kurdish/24935503.html

IHS Jane's. (2014). Leadership reshuffle - PKK Makes Changes in Its Ranks. URL:http://www.washingtoninstitute.org/uploads/Documents/opeds/Cagaptay20140226-

Janes.pdf

Bozarslan, M. (2015). “Why the PKK is So Interested in Mosul.” Al-Monitor. URL: http://www.al-monitor.com/pulse/originals/2016/04/turkey-iraq-syria-pkkinterest-in-mosul.html\#ixzz4RsYzmNki

${ }^{56}$ Candar, C. (2012). “Turkey Claims Iran Providing Logistical Support for PKK.” Al-Monitor. URL:http://www.al-monitor.com/pulse/originals/2012/al-monitor/iranturkey-shiite-sunni-pkk.html\#ixzz4F3J33gkt

57 In 2007, STRATFOR estimated the PKK makes \$300-400 million per year from related activities. Another source puts the PKK’s budget at its peak in the 1990s at about $\$ 86$ million per year. In 2002, Germany's chief prosecutor asserted that "80 percent of narcotics seized in Europe were linked to the PKK or "other Turkish groups" which then have used the profits from illegal narcotics to purchase arms." https://www.loc.gov/rr/frd/pdf-files/WestEurope_NEXUS.pdf p. 20. See also https://www.treasury.gov/press-center/press-releases/Pages/tg1406.aspx; http://www.al-monitor.com/pulse/originals/2013/01/ocalan-tukspkk.html\#ixzz4FifcTzAR

${ }^{58}$ Abdullah. Sh. (2014). “Yazidis Form Militia To Protect Sinjar Mountain.” ANIA. URL: http://www.aina.org/news/20140806125221.htm

${ }^{59}$ Paraszczuk, J. (2015). "Yazidi Militias Fight IS In Iraq, Amid Kurdish Rivalries.” Radio Free Europe Radio Liberty. URL: http://www.rferl.org/content/islamic-stateyazidi-militias-kurdish-region/27066780.html

${ }^{60}$ Van den Toorn, C. (2016). “The Wars after the War for Sinjar. How Washington Can Avert a New Civil War.” War on the Rocks. URL:

http://warontherocks.com/2016/06/the-wars-after-the-war-for-sinjar-how-washington-can-avert-a-new-civil-war/

${ }^{61}$ Van den Toorn, C. (2016). “The Wars after the War for Sinjar. How Washington Can Avert a New Civil War.” War on the Rocks. URL:

http://warontherocks.com/2016/06/the-wars-after-the-war-for-sinjar-how-washington-can-avert-a-new-civil-war/

${ }^{62} \mathrm{PAX}$ for Peace. (2016). Sinjar after ISIS: Returning to disputed territory. URL: https://www.paxforpeace.nl/stay-informed/news/sinjar-after-isis-returning-to-

disputed-territory

THIS IS A DRAFT WORKING PAPER: NOT FOR DISTRIBUTION OR CITATION 
${ }^{63}$ Moore, J. (2015). “'4,000-Strongs' Christian Militias Formed to Fight ISIS in Northern Iraq.” Newsweek. URL: http://europe.newsweek.com/4000-strong-christianmilitia-formed-fight-isis-northern-iraq-304371? rm=eu 